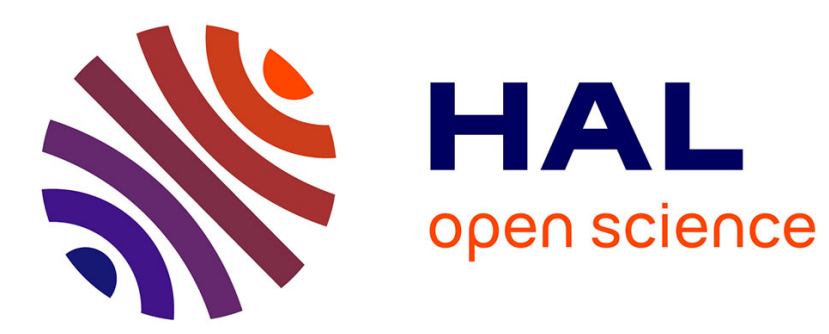

\title{
Trace metal behaviour in riverine sediments: role of organic matter and sulphides
}

Adeline Charriau, Ludovic Lesven, Yue Gao, Martine Leermakers, Willy Baeyens, Baghdad Ouddane, Gabriel Billon

\section{To cite this version:}

Adeline Charriau, Ludovic Lesven, Yue Gao, Martine Leermakers, Willy Baeyens, et al.. Trace metal behaviour in riverine sediments: role of organic matter and sulphides. Applied Geochemistry, 2010, 26 (1), pp.80-90. 10.1016/j.apgeochem.2010.11.005 . hal-00922200

\section{HAL Id: hal-00922200 \\ https://hal.science/hal-00922200}

Submitted on 24 Dec 2013

HAL is a multi-disciplinary open access archive for the deposit and dissemination of scientific research documents, whether they are published or not. The documents may come from teaching and research institutions in France or abroad, or from public or private research centers.
L'archive ouverte pluridisciplinaire HAL, est destinée au dépôt et à la diffusion de documents scientifiques de niveau recherche, publiés ou non, émanant des établissements d'enseignement et de recherche français ou étrangers, des laboratoires publics ou privés. 
Trace metal behaviour in riverine sediments: role of organic matter and sulphides

\section{Authors}

Adeline Charriau ${ }^{a}$, Ludovic Lesven ${ }^{a}$, Yue Gao $^{b}$, Martine Leermakers $^{b}$, Willy Baeyens ${ }^{b}$, Baghdad Ouddane $^{a}$, Gabriel Billon ${ }^{a}$

${ }^{a}$ Université Lille 1 Sciences et Technologies. Laboratoire Géosystèmes (FRE-CNRS 3298). 59655 Villeneuve d'Ascq, France

${ }^{\mathrm{b}}$ Department of Analytical and Environmental Chemistry (ANCH), Vrije Universiteit Brussel (VUB), B-1050 Brussels, Belgium

\section{Corresponding author}

Gabriel Billon

gabriel.billon@univ-lille1.fr

Tel: +33 320434929

Fax: +33 320434822

adeline.charriau@univ-lille1.fr

ludovic.lesven@univ-lille1.fr

baghdad.ouddane@univ-lille1.fr

yuegao@vub.ac.be

wbaeyens@vub.ac.be

mleermak@vub.ac.be 


\begin{abstract}
Three sediment cores were collected in the Scheldt, Lys and Spiere canals, which drain a highly populated and industrialized area in Western Europe. The speciation and the distribution of trace metals in pore waters and sediment particles were assessed through a combination of computational and experimental techniques. The concentrations of dissolved major and trace elements (anions, cations, sulphides, dissolved organic carbon, $\mathrm{Cd}, \mathrm{Co}, \mathrm{Fe}$, $\mathrm{Mn}, \mathrm{Ni}, \mathrm{Pb}$ and $\mathrm{Zn}$ ) were used to calculate the thermodynamic equilibrium speciation in pore waters and to evaluate the saturation of minerals (Visual Minteq software). A sequential extraction procedure was applied on anoxic sediment particles in order to assess the main hosting phases of trace elements.

Manganese was the most labile metal in pore waters and was mainly associated to carbonates in particles. On the contrary, a weak affinity of $\mathrm{Cd}, \mathrm{Co}, \mathrm{Ni}, \mathrm{Pb}$ and $\mathrm{Zn}$ with carbonates was established because (1) a systematic under-saturation was noticed in pore waters and (2) less than $10 \%$ of these elements were extracted in the exchangeable and carbonate sedimentary fraction.

In the studied anoxic sediments, the mobility and the lability of trace metals, apart from manganese, seemed to be rather controlled through the competition between sulphidic and organic ligands. In particular, the necessity of taking into account organic matter in the modelling of thermodynamic equilibrium was demonstrated for $\mathrm{Cd}, \mathrm{Ni}, \mathrm{Zn}$ and $\mathrm{Pb}$, the latter element exhibiting the stronger affinity with humic substances. Consequently, dissolved organic matter could favour the stabilization of trace metals in the liquid phase. Conversely, sulphide minerals played a key role in the scavenging of trace metals in sediment particles. Finally, similar trace metal lability rankings were obtained for the liquid and solid phases.
\end{abstract}

\title{
Key words
}

Sediment, trace metal, speciation, thermodynamic equilibrium, sulphides, organic matter 


\section{Introduction}

Metallic contaminants released by past and present human activities are known to accumulate in the environment and in particular in river sediments. However, sediments are complex and heterogeneous media and their role as a potential sink or source of contaminants is not yet fully understood. A large number of biogeochemical processes are involved, influencing the fate of trace metals. Among these processes, the microbial degradation of organic matter during early diagenesis leads to major changes in the redox conditions between the overlying oxic waters and the oxygen-depleted sediments (Baker, 1994; Stumm and Morgan, 1981). As a result, strong vertical gradients are evidenced for dissolved species concentrations in the vicinity of the water-sediment interface, resulting in the release or the trapping of trace metals in sediments (Audry et al., 2010; Canavan et al., 2007, Miller and Orbock Miller, 2007). Moreover, resuspension events from natural or anthropogenic origin can disturb the biogeochemistry of sediments and potentially favour the remobilisation of trace metals from sediment particles to the water column (Caetano et al., 2003; Cantwell et al., 2002; Saulnier and Mucci, 2000). Even if sediments represent a potential threat for the aquatic biota and the management of water quality, this compartment is not yet taken into account by the Water Framework Directive of the European Union (Directive 2000/60/EC) when evaluating the chemical quality of a water body (Borja et al., 2004; Crane, 2003).

In this context, studying the distribution of dissolved and particulate trace metals in sediments appears to be of a high concern as speciation strongly influences the fate of these contaminants in the aquatic environment, including their transport, persistence, toxcity and bioavailability (Kramer and Allen, 1988; Tessier and Turner, 1995; Ure and Davidson, 2002). In anoxic sediments and pore waters, the experimental determination of trace metal speciation is a challenging task for the following reasons: the low concentrations of metallic species, the complexity of the sedimentary matrix and the instability of some phases, such as sulphides. These difficulties and the risk of artefacts during the sample treatment and analysis make thermodynamic calculations a promising approach for the evaluation of trace 
metal speciation (Billon et al., 2003; Canavan et al., 2007; Huerta-Diaz et al., 1998; LourinoCabana et al., 2010; Mayer et al., 2008; van den Berg et al., 1999).

This study has been made in the framework of the European INTERREG III STARDUST research program, which aimed at investigating the risk associated to contaminated sediments in three transborder rivers of France and Belgium (the Scheldt, the Spiere Canal and the Lys River). The software Visual Minteq, incorporating the NICA-Donnan model for organic matter-trace metal interactions, has been applied to predict the pore water speciation of cadmium, cobalt, iron, lead, manganese, nickel and zinc. In sediment particles, a sequential extraction procedure was performed to determine the main hosting phases of trace metals. The combination of these modelling and experimental results has permitted: (i) to examine more precisely the distribution of trace metals in pore waters and sediments particles, (ii) to evaluate the relative contributions of carbonates, sulphides and organic ligands and (iii) to gain some new information on the mobility of trace metals in anoxic riverine sediment subject to metallic anthropogenic inputs.

\section{Materials and methods}

\subsection{Study area and sampling}

The Scheldt River flows through France, Belgium and the Netherlands in one of the most industrialised and urbanised area of Western Europe. Its catchment area covers $21,860 \mathrm{~km}^{2}$ and includes approximately 10 millions inhabitants. Since the middle of the $19^{\text {th }}$ century, industrial activities, including coal mining, metallurgical plants, textile and chemical industries, have led to high inputs of both metallic and organic contaminants in the Scheldt River and its tributaries. A decrease of the industrial activity and the efforts made in terms of regulation led to significant improvements of the water quality in this area. However, numerous of sediments are still highly polluted and may now act as a potential "time bomb", particularly in case of disturbing events.

Sediments were collected in November and December 2005 in the Scheldt River (at Helkijn) and two of its tributaries (the Lys River at Wervik and the Spiere Canal) (Figure 1). According 
to the Water Framework Directive of the European Union (Directive 2000/60/EC), these water bodies are at risk of failing to achieve a good ecological status (or potential) by the year 2015. In the Scheldt River, samplings were performed in a relatively protected area out of the main stream, approximately $500 \mathrm{~m}$ downstream the confluence with the Spiere Canal and $100 \mathrm{~m}$ upstream the lock of Helkijn. At this station, the averaged flow was $15 \mathrm{~m}^{3} \cdot \mathrm{s}^{-1}$. The Spiere Canal is an artificial waterway (with an annual flow around $0.8 \mathrm{~m}^{3} \cdot \mathrm{s}^{-1}$ ), connecting the Deûle and Scheldt Rivers. In this study, sediment cores were collected approximately $100 \mathrm{~m}$ upstream the confluence with the Scheldt. In the Lys River, which is the major tributary of the Scheldt in Flanders with an averaged flow of $23 \mathrm{~m}^{3} \cdot \mathrm{s}^{-1}$, sediment samplings were performed in a backwater of the river in order to limit the sediment disturbance due to navigation (Figure 1).

Sampling, field analyses and core treatment are described in detail in previous studies (Charriau et al., 2009; Lesven et al., 2008). Briefly, the sediment cores (approximately $20 \mathrm{~cm}$ length and $10 \mathrm{~cm}$ diameter) were collected by a diver at each sampling site. One of the sediment cores was dedicated to $\mathrm{pH}$ and redox potential measurements, which were performed directly in the field using combined glass and platinum electrodes (reference electrode $\mathrm{Ag} / \mathrm{AgCl},[\mathrm{KCl}]=3 \mathrm{M}$ in both cases). Another sediment core was cut every $2 \mathrm{~cm}$ under nitrogen in a glove bag to prevent any oxidation of the reduced species present in the anoxic sediments. In the laboratory, sediment slices were centrifuged (3000 rpm) and the extracted pore waters were immediately filtered (Whatman, $0.45 \mu \mathrm{m}$ ) under nitrogen, mainly to avoid the oxidation of $\mathrm{Fe}(\mathrm{II}), \mathrm{Mn}(\mathrm{II})$ and $\mathrm{S}(-\mathrm{II})$.

\subsection{Sediment particles analysis}

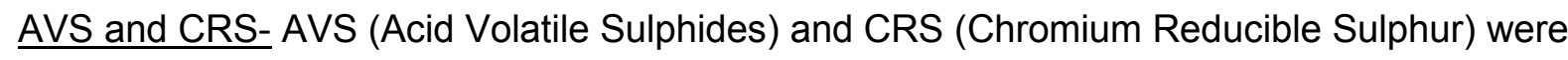
evaluated on wet sediments following a two successive steps procedure described by Canfield et al. (1986), Cornwell and Morse (1987) and more recently by Billon et al. (2001c). Distribution of metals using sequential extraction- A sequential extraction procedure, developed by Quevauvillier et al. (1996) and modified by Rauret et al. (1999), was chosen to 
determine the distribution of major and trace elements into the main hosting phases of sediment particles. The succession of reagents used in this study allows for the estimation of four operationally-defined fractions: (1) exchangeable and acid-soluble, (2) reducible, (3) oxidizable and (4) residual. Several artefacts and difficulties may be encountered when applying a sequential extraction procedure to anoxic sediments. One of the main problems is the correspondance between an operationally-defined fraction and the natural mineral or metal host fraction present in the sediment; this is especially true for volatile sulphide compounds (Billon et al., 2001a; Peltier et al., 2005; Rapin et al., 1986). Hjorth (2004), Kersten and Forstner (1986), Larner et al. (2008) and Rapin et al. (1986) underlined in their studies that the maintenance of oxygen-free conditions during the first two steps of the extraction procedure is of critical importance and that the freeze- or oven-drying of sediments should be avoided. In the present study, anoxic conditions were preserved by manipulating wet sediment samples under a controlled $\mathrm{N}_{2}$ atmosphere and by using deoxygenated reagents and solutions.

Trace elements were analysed using inductively coupled plasma - atomic emission spectroscopy (ICP-AES, Vista Pro Varian, axial view) or inductively coupled plasma - mass spectrometry (ICP-MS, X Series Thermo Elemental), depending on the concentration range. The standard solutions were prepared in the extracting reagents to account for potential matrix effects. An international certified reference sediment (CRM 601 from the European Community Bureau of Reference) was analysed for quality control at each extraction step. Certified and measured concentrations were found in good agreement and recoveries were higher than $84 \%$ (supplementary data).

\subsection{Pore water analysis}

The complete description of the analyses performed on pore water samples can be found in Lesven et al. (2008). Briefly, the concentrations of anions $\left(\mathrm{NO}_{3}{ }^{-}, \mathrm{SO}_{4}{ }^{2-}\right.$ and $\left.\mathrm{PO}_{4}{ }^{3-}\right)$ were measured by ionic chromatography (Dionex). Cathodic stripping square wave voltametry (CSSWV) was applied to determine the concentration of reduced sulphur species S(-II) 
[Batina et al. (1992) and Billon et al. (2001b)]. Dissolved organic carbon (DOC) was measured with a Skalar apparatus (model Formacs). Concentrations of major elements (Al, $\mathrm{Ca}, \mathrm{Mg}, \mathrm{Na}, \mathrm{Si}, \mathrm{Sr}$ ) and trace metals ( $\mathrm{Cd}, \mathrm{Co}, \mathrm{Fe}, \mathrm{Mn}, \mathrm{Ni}, \mathrm{Pb}, \mathrm{Zn}$ ) were determined in pore waters using ICP-AES or ICP-MS, depending on their concentration range, and used as input data for the thermodynamic equilibrium model.

\subsection{Thermodynamic calculations}

The software Visual Minteq (version 2.40b) was used to calculate the equilibrium composition of pore waters, and also to predict some precipitation/dissolution processes. (Visual MINTEQ, 2010). It includes two sub-models (NICA-Donnan and Stockholm Humic Model) allowing for the consideration of trace metal - humic substances interactions. Humic substances consist of a wide range of compounds, which are generally fractioned into fulvic acids (FA) and humic acids (HA) and differ in terms of size, properties and type of functional groups. The NICA-Donnan model supposes a bimodal and continuous distribution of site affinities (Benedetti et al., 1995) whereas the Stockholm humic model (SHM) employs a discrete distribution of binding sites (Gustafsson, 2001). In this paper, both OM models were used and the output data were very similar (excepted for iron and to a lesser extent $\mathrm{Zn}$, two metals that are less complexed by humic substances using the SHM model). As a consequence, only the results related to the Nica-Donnan model will be further discussed in this paper.

Input data consisted of the pore water concentrations of the following components: $\mathrm{Ca}^{2+}, \mathrm{K}^{+}$, $\mathrm{Mg}^{2+}, \mathrm{Na}^{+}, \mathrm{Sr}^{2+}, \mathrm{Cd}^{2+}, \mathrm{Co}^{2+}, \mathrm{Fe}^{2+}, \mathrm{Mn}^{2+}, \mathrm{Ni}^{2+}, \mathrm{Pb}^{2+}$ and $\mathrm{Zn}^{2+}$ and of the following inorganic metal binding ligands: $\mathrm{CO}_{3}{ }^{2-}, \mathrm{HS}^{-}, \mathrm{NO}_{3}{ }^{-}, \mathrm{OH}^{-}, \mathrm{PO}_{4}{ }^{3-}$ and $\mathrm{SO}_{4}{ }^{2-}$. Parameters such as $\mathrm{pH}$, ionic strength and temperature were also considered. The concentrations of humic substances were deduced from dissolved organic carbon (DOC) measurements, considering that organic matter was $70 \%$ active (Balistrieri and Blank, 2008). During a preliminary study (Charriau, 2009), several calculations have been made, first in the absence of organic matter (referred to as "no OM" hereafter in the text) and then considering 3 organic matter compositions: 
$100 \%$ FA, $100 \%$ HA or $80 \% F A-20 \%$ HA (Meylan et al., 2004). Trace metal speciation results differed slightly between the $3 \mathrm{OM}$ compositions. This confirms that even if the OM composition is only roughly known in pore waters, the dissolved metal speciation can be relatively well approximated.

The output database includes the metal predicted speciation in pore waters and also the saturation index $(\mathrm{SI})$, which measures the extent of pore water saturation with respect to a mineral phase. It is defined as: $\mathrm{SI}=\log \left(\mathrm{IAP} / \mathrm{K}_{\mathrm{sp}}\right)$, where IAP represents the calculated ionic activity product, which is compared to the solubility product $\left(\mathrm{K}_{\mathrm{sp}}\right)$ of the studied mineral phase. Hence, pore water is considered as supersaturated when $\mathrm{SI}>0$, saturated when $\mathrm{SI} \sim$ 0 and undersaturated when $\mathrm{SI}<0$.

\section{Results}

\subsection{Geochemical features}

Sediments were dominated by fine grain particles, containing less than $5 \%$ of particulate organic matter, whatever the site and the depth (Charriau et al., 2009), and were especially contaminated by Cd, Pb and Zn (Lesven et al., 2008). Overall, Spiere sediment particles exhibited the highest contamination level, probably because of the high industrial activity and the runoff on abandoned industrial wastelands upstream the sampling site. The sulphidization processes were very similar for Helkijn and Wervik sites, with a production of AVS (acid volatile sulphides) and CRS (chromium reducible sulphur) just below the watersediment interface. In Spiere sediment, AVS and CRS contents were much higher, reaching up to 3,000 and $2,000 \mathrm{mg} \cdot \mathrm{kg}^{-1}$, respectively. The sulphidization process was not fully completed in the three sites, probably because of a lack of sulphate input in Helkijn and Wervik pore waters and a lack of biodegradable organic matter in Spiere sediments (Lesven et al., 2008).

Pore waters in Spiere sediments were characterized by negative redox potential values ($400 \mathrm{mV}$ vs $\mathrm{Ag} / \mathrm{AgCl}$ at $-10 \mathrm{~cm}$ ), low alkalinity values (in the range of 5 to $7 \mathrm{mM}$ ) and lower DOC (dissolved organic carbon) values, (19.2 - $36.9 \mathrm{mg} . \mathrm{L}^{-1}$ ) compared to Helkijn and Wervik 
sites. For these two sites, DOC contents increased with depth up to $120 \mathrm{mg} \cdot \mathrm{L}^{-1}$. In Helkijn and Wervik sediments, alkalinity ranged from $6 \mathrm{mM}$ at the water-sediment interface to $25 \mathrm{mM}$ at $-25 \mathrm{~cm}$. $\mathrm{pH}$ values were significantly lower in Wervik sediments (values below 6.5 from -5 $\mathrm{cm}$ ) than in Spiere and Helkijn sediments (lowest values close to 6.6 at the bottom of the sediment cores). Finally, dissolved sulphides concentrations fluctuated in the three sedimentary stations between $70 \mathrm{nM}$ and $1300 \mathrm{nM}$, without any clear trend (Lesven et al., 2008).

\subsection{Distribution of anions and major species in sediment particles and pore waters}

The following anions were considered in pore waters: $\mathrm{SO}_{4}{ }^{2-}, \mathrm{PO}_{4}{ }^{3-}$ and $\mathrm{CO}_{3}{ }^{2-}$. According to our calculations in pore waters, most of the inorganic carbon was present as $\mathrm{HCO}_{3}{ }^{-}$and to a lesser extent $\mathrm{H}_{2} \mathrm{CO}_{3} . \mathrm{SO}_{4}{ }^{2-}$ and $\mathrm{HPO}_{4}{ }^{2-}$ were the main species in our samples although 20-30 $\%$ of sulphates and phosphates were associated with magnesium $\left(\mathrm{MgSO}_{4}\right.$ and $\mathrm{MgHPO}_{4}$, respectively) and calcium $\left(\mathrm{CaSO}_{4}\right.$ and $\mathrm{CaHPO}_{4}$, respectively).

A relevant part of sulphides was complexed with iron as $\mathrm{FeHS}^{+}$when $\mathrm{OM}$ was not taken into account in the calculations. The lower $\mathrm{FeHS}^{+}$calculated values for Spiere pore waters were due to lower dissolved $\mathrm{Fe}^{2+}$ contents, compared to those found in Helkijn and Wervik. The three other main species were $\mathrm{MnHS}^{+}, \mathrm{HS}^{-}$and $\mathrm{H}_{2} \mathrm{~S}$. The addition of humic substances into the model enhanced non-sulphide complexation of $\mathrm{Fe}^{2+}$, thus resulting in a significant decrease of the $\mathrm{FeHS}^{+}$fraction in Spiere pore waters.

In pore waters, the major elements $\mathrm{Ca}, \mathrm{Mg}, \mathrm{K}, \mathrm{Na}$ and $\mathrm{Sr}$ were mainly present as free cations. In sedimentary particles, $\mathrm{Ca}$ and to a lesser extent $\mathrm{Sr}$, were mainly associated to the "exchangeable and carbonate" fraction, whereas Mg was mainly bound to refractory minerals (> 56\%) (data not shown). Note further that only calcite showed a diffraction response in sediment particles. It has been calculated that calcite represents the main carbonate mineral and accounts for approximately $10 \%$ in weight of the total sediment particles.

\subsection{Trace metals distribution in sediment particles and pore waters}


The profiles of dissolved trace metal concentrations obtained after the centrifugation of pore waters can be found in Lesven et al. (2008). Our calculated speciations in pore waters are displayed figures 2 and 3 while the results of the sequential extractions of sediment particles are shown in figure 4.

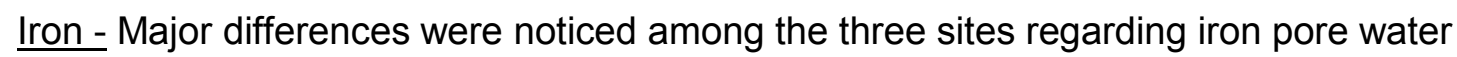
concentrations. Helkijn and Wervik profiles were characterized by a strong increase from the interface (values close to $1.4 \mathrm{mg} \cdot \mathrm{L}^{-1}$ ) to the bottom of the core (values close to $11.0 \mathrm{mg} \cdot \mathrm{L}^{-1}$ ), while iron concentrations in Spiere pore waters were 10 times lower and almost constant with depth. When thermodynamic equilibrium calculations were performed without humic substances, the main iron species was $\mathrm{Fe}^{2+}$ in connection with the relatively low dissolved sulphides contents (Figure 2). The addition of humic substances into the model resulted in a significant complexation of iron, especially with carboxylic groups.

In sediment particles, iron was preferentially present in the residual fraction (30-76\%), especially in Wervik and Helkijn sites (Figure 4). The second fraction, which includes most of the AVS compounds generated during early diagenetic processes (Billon et al., 2001a), accounted for $10-33 \%$ of total iron for Helkijn and Wervik sites and $28-45 \%$ for Spiere sediments. Conversely, iron was poorly associated to the third fraction, which includes pyritic compounds and associations with organic matter, and to the first fraction.

Manganese - The values of dissolved manganese concentrations were similar for the three sites in surficial sediments $\left(\sim 0.5 \mathrm{mg} \cdot \mathrm{L}^{-1}\right)$. For Wervik and Helkijn sites, dissolved $\mathrm{Mn}$ concentrations increased with depth to reach $1 \mathrm{mg} \cdot \mathrm{L}^{-1}$ at the bottom of the cores, while the concentration profile was more constant for Spiere sediments. According to our calculations, $\mathrm{Mn}^{2+}$ was the main species (>60\%) at the three sites (Figure 3). Manganese was poorly associated to humic substances, so that their introduction in the model did not change significantly the Mn speciation predicted in porewaters without organic matter.

In the solid phase, the exchangeable and carbonate fraction was predominant for almost all samples (35-65\%), while less than $5 \%$ of manganese was extracted in the oxidizable fraction (Figure 4). 


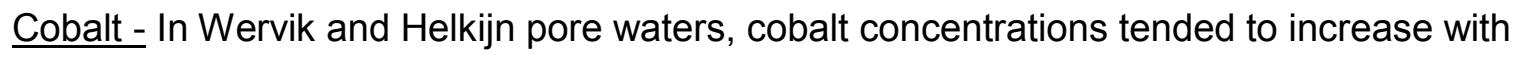
depth, after a subsurface maximum. Spiere pore waters differed by a lower cobalt level (values below $1 \mu \mathrm{g} . \mathrm{L}^{-1}$ ) and by a slightly decreasing trend with depth. For the three sites, the main species present in porewaters were the free ion $\mathrm{Co}^{2+}$ (Figure 2). Regarding organic complexes, cobalt tended to associate more strongly with humic acids (3-10\%) than with fulvic acids (1-3\%).

In sediment particles, cobalt was mostly present in the residual fraction for Wervik (58-66 \%) and Helkijn (37-63\%), while the third fraction was predominant for Spiere sediments (36-45 \%) (Figure 4). About $20-40 \%$ of cobalt were associated to the first two fractions ("exchangeable and carbonates" and reducible).

Nickel - Nickel also showed a sub-surface maximum. Concentrations in Wervik and Helkijn pore waters decreased rapidly with depth, from maximum concentrations observed in surficial pore waters (19 and $11 \mu \mathrm{g} \cdot \mathrm{L}^{-1}$, respectively) to minimum values noticed at $-5 \mathrm{~cm}$ (6 and $7 \mu \mathrm{g} \cdot \mathrm{L}^{-1}$, respectively). As for other trace metals (i.e. Co, Fe and $\mathrm{Mn}$ ), Spiere pore waters differed by lower dissolved nickel concentrations $\left(2-4 \mu \mathrm{g} \cdot \mathrm{L}^{-1}\right)$ and more constant values as a function of depth. The calculated speciation of nickel was similar to the one of cobalt with two main inorganic species: $\mathrm{Ni}^{2+}$ and $\mathrm{NiHCO}_{3}{ }^{+}$(Figure 3). However, compared to cobalt, nickel exhibited a higher affinity toward fulvic acids (12-33\%).

The distribution of nickel in sediment particles was very similar to the one of cobalt (Figure 4). Nickel remained largely associated with refractory minerals ( 40\%), except for Spiere sediments, where nickel was almost equally bound to the reducible, oxidizable and residual fractions (approximately 30-35\% for each one).

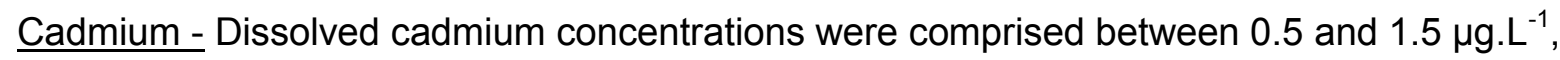
and were more or less constant with depth, whatever the sampling site considered. Without OM in the input data, a strong association was noticed between cadmium and sulphides especially in Spiere pore waters (Figure 2). The other main species were the free $\mathrm{Cd}^{2+}$ cation and the carbonate complexes. The addition of humic substances into the model changed radically the speciation of cadmium. In Wervik and Helkijn sites, the association of $\mathrm{Cd}^{2+}$ with 
humic substances dominated (44-70\%), whereas the contribution of organic complexes ranged between 8 and $41 \%$ in Spiere pore waters.

The main hosting phases for cadmium were the reducible fraction for Helkijn and Wervik stations (47-71\%), and the oxidizable fraction for Spiere sediments (67-87\%). Cadmium was poorly associated to the residual fraction of sediment particles (less than 15\%), and was almost absent in the exchangeable and carbonate fractions (less than 4\%) (Figure 4). Lead - For the three sites, dissolved $\mathrm{Pb}$ concentrations ranged from 5 to $12 \mu \mathrm{g} \cdot \mathrm{L}^{-1}$. The contents were maximum at the water-sediment interface and decreased subsequently and slowly with depth. Without OM, the calculations indicated that lead was mainly associated with carbonates in Helkijn and Wervik pore waters (75-93\%), while the sulphidic species $\mathrm{Pb}(\mathrm{HS})_{2}$ competed significantly in Spiere pore waters (28-85 \%) (Figure 3). The addition of humic substances resulted in a quantitative (94-99\%) complexation of $\mathrm{Pb}^{2+}$, mainly with phenolic groups.

As shown in Figure 4, the distribution of cadmium and lead in sediments were very similar: lead was mainly associated with oxides and probably with reactive sulphides in Helkijn and Wervik sediments (44-75\%), whereas the third fraction (organic and pyritic compounds) was predominant for Spiere particles (51-84\%).

Zinc - Dissolved Zn concentrations fluctuated around an average value of 5, 17 and $29 \mu \mathrm{g} \cdot \mathrm{L}^{-1}$ for Wervik, Helkijn and Spiere pore waters, respectively and with no particular trend as a function of depth. When organic matter was not considered in our calculations, the major species were $\mathrm{Zn}^{2+}(64-84 \%)$ and the carbonated complexes $\mathrm{ZnCO}_{3(\mathrm{aq})}$ and $\mathrm{ZnHCO}_{3}{ }^{+}$(14-31 \%) (Figure 3). Only humic acids complexed quantitatively $\mathrm{Zn}^{2+}$, especially in Wervik (62-85 $\%)$ and Helkijn (45-69 \%) pore waters.

The distribution of zinc in sediment particles was quite similar for the three sites: most of $\mathrm{Zn}$ was associated to the reducible fraction $(45-71 \%)$, followed by the oxidizable fraction (16$33 \%$ ) whereas the two other fractions were less significant (Figure 4).

Overall, the predicted trace metal speciation in pore waters, estimated via the Visual Minteq modelling software appears to be a satisfactory but preliminary approach of the much more 
complex reality. Several thermodynamic equilibrium constants are simply not known with a good precision, especially those related to metal-(poly)sulphides (Rickard and Morse, 2005) and metal-natural organic matter associations (Tipping, 2002; Filella and Town, 2005). The colloidal fraction, which can play a key role in trace metal speciation and mobility, was also omitted from the calculations due to the difficulties of analyzing this fraction in anoxic pore waters. In the past, some experiments have been carried out by Billon (2001) to analyze colloids in pore waters by using ultrafiltration and photon correlation spectroscopy (PCS 4700 spectrometer, Malvern). In both cases, although the samples were strictly kept under nitrogen, the results were not reproducible. Attempts were also made with the DET technique to assess the non-labile dissolved metal fraction (colloids + strong metal complexes) in pore waters. Unfortunately, the blanks were too high for most of the trace metals so that no valid results could be obtained.

\section{Discussion}

\subsection{Mobility of trace metals: the role played by the carbonates species}

The "exchangeable and carbonate" fraction is considered to be one of the most available regarding organisms and plants; trace metals associated to this fraction can become mobile in case of environmental changes (Miller and Orbock Miller, 2007). In sulphidized sediments, mobilization of trace metals from AVS must also be considered since AVS oxidation can result in a fast release of trace metals previously associated with sulphides (Saulnier and Mucci, 2000). Note further that previous studies have pointed out that a significant part of AVS can be dissolved during the first extraction step (Billon et al., 2001a). In our anoxic sediments, the first fraction called "exchangeable and carbonates" contains thus also the most easily acid soluble sulphide compounds.

In competition with the sulphide and organic fractions, carbonates are known to partially control the mobility of divalent trace metals through several mechanisms, including sorption and/or coprecipitation (Crocket and Winchester, 1966; Davis et al., 1987). 
Negative saturation index values were found for $\mathrm{SrCO}_{3}$ in pore waters while $\mathrm{Sr}$ was, according the sequential extraction measurements, essentially associated with carbonates $(41-58 \%)$ in sediment particles. These two findings suggest that $\mathrm{SrCO}_{3}$ does not exist as a pure mineral in pore waters but is rather included as a solid solution $\mathrm{Ca}_{1-x} \mathrm{Sr}_{x} \mathrm{CO}_{3}$ in calcite minerals (Pingitore et al., 1992; Tesoriero and Pankow, 1996). Magnesium, which is a major component of several clay minerals, was mostly present in the residual fraction (56-73\%). The presence of magnesium in the carbonate fraction accounted for about $15 \%$ of total $\mathrm{Mg}$. However, the pure minerals $\mathrm{MgCO}_{3}$ and $\mathrm{CaMg}\left(\mathrm{CO}_{3}\right)_{2}$ were not observed in the $\mathrm{X}$ ray diffraction spectra and the saturation indexes for these two minerals were rather negative. These findings suggested that Mg was also present under solid solution compounds, such as: $\mathrm{Ca}_{1-\mathrm{x}} \mathrm{Mg}_{\mathrm{x}} \mathrm{CO}_{3}$. As shown in Figure 4, manganese was mostly associated to the exchangeable and carbonate fraction (30-70\%). The presence of a $\mathrm{Ca}_{x} \mathrm{Mn}_{\mathrm{x}-1} \mathrm{CO}_{3}$ solid solution has been confirmed through ESR (electron spin resonance) measurements (data not shown) and was in agreement with numerous other studies (see for instance: Billon et al., 2002; Morse and Arakaki, 1993; Ouddane et al., 2001; Pingitore et al., 1988). For Spiere and Helkijn sites, the saturation of pure $\mathrm{MnCO}_{3}$ was reached in pore waters, suggesting the possible presence of authigenic rhodocrosite in sediment, even if this mineral couldn't be directly evidenced using X-ray diffraction and spectroscopic techniques. In porewaters, the relatively high concentration of manganese and the weak association of $\mathrm{Mn}^{2+}$ with other ligands, either organic or inorganic, agree well with its relatively high lability in the solid phase.

The higher iron concentrations and alkalinity values in Wervik and Helkijn pore waters resulted in a saturation of siderite $\left(\mathrm{FeCO}_{3}\right)$ all along the sediment cores. On the contrary, Spiere pore waters were characterized by lower alkalinity values and an undersaturation of $\mathrm{FeCO}_{3}$. It is also important to remind that Spiere sediments differed by higher AVS and CRS contents, which can result in an efficient scavenging of iron in particles and thus in a relatively low iron concentration in pore waters (Lesven et al., 2008). However, if we assume that the most unstable FeS compounds were dissolved during the first extraction step, and 
the remaining AVS fraction during the second extraction step (Billon et al., 2001a; Peltier et al., 2005; Wallmann et al., 1993), it was not surprising to detect significant Fe amounts in the exchangeable and carbonate fraction, even in Spiere sediments.

Trace metals ( $\mathrm{Cd}, \mathrm{Co}, \mathrm{Ni}, \mathrm{Pb}$ and $\mathrm{Zn}$ ) were systematically undersaturated with respect to their carbonate minerals $\mathrm{MeCO}_{3}$, so that carbonates seemed not to control the pore water concentrations of these trace metals. In sediment particles, the weak affinity between carbonates and the previous trace metals was confirmed by the sequential extraction results (Figure 4). Indeed, the exchangeable and carbonates fraction was barely detectable for $\mathrm{Cd}$ and $\mathrm{Pb}$, while it accounted for less than $10 \%$ in the case of $\mathrm{Co}, \mathrm{Ni}$ and $\mathrm{Zn}$. These results were globally in agreement with those obtained from the predictive speciation in pore waters. Trace metals significantly present as free cations in the dissolved phase (mostly Co and $\mathrm{Ni}$ ) were also present in the sedimentary carbonate fraction, whereas $\mathrm{Cd}$ and $\mathrm{Pb}$, which were mostly associated with dissolved organic matter and/or sulphides in pore water, were barely present in the particulate carbonate fraction.

\subsection{Competition between sulphides and organic matter for strong associations with trace metals}

In aerobic media, the availability and fate of trace metals are closely related to the iron and manganese oxide fraction, whereas in more anoxic conditions, the sulphide pool plays a predominant role in the distribution of trace elements (DiToro et al., 1990; Miller and Orbock Miller, 2007; Saulnier and Mucci, 2000). Indeed in anoxic sediments, sulphides produced from sulphate reducing bacteria are either reoxidized or precipitated with numerous trace metals, especially $\mathrm{Fe}(\mathrm{II})$. The speciation of these metals $(\mathrm{Me})$ is strongly influenced by the direct formation of MeS, the co-precipitation with iron sulphides, and/or the adsorption processes taking place on sulphide minerals (Morse and Luther, 1999). For that reason, the concentration of trace metals in pore waters generally remains at $\mathrm{ppb}$ levels or even less. Near the water-sediment interface of the three sediment cores, iron and manganese oxides became reduced with the concomitant oxidation of the biodegradable organic matter, which 
may contain large amounts of trace metals. Because of the higher redox potential values observed at the interface (especially in Wervik and Helkijn sediments), the quantitative reoxidation of the produced sulphide species limited the precipitation of trace metal sulphides (Berner, 1984; Jorgensen, 1982). As a result, higher concentrations of iron, manganese, cobalt, nickel and lead were present in the surficial pore waters, compared to those measured in the overlying waters. In Spiere sediments, the release of trace metals in pore waters was less pronounced for iron, cobalt and nickel. The redox potential, which was already negative at the sediment surface, resulted in a more efficient scavenging of these metals in the sulphide pool (Lesven et al., 2008). Iron sulphides (AVS and CRS) were detected at the three sites whatever the depth, but with lower AVS contents in the surface sediments because of the reoxidation of the most unstable sulphides. The sequential extraction procedure for iron was not able to clearly separate sulphides, oxides and the organic fraction. According to previous studies (Billon et al., 2001a; Peltier et al., 2005; Wallmann et al., 1993), AVS-Fe species are mostly present in the first two fractions, whereas pyritic compounds were mostly recovered during the second and third fractions (Rickard and Morse, 2005). The results indicated that about $30-60 \%$ of iron was present in the two most labile fractions, so that the distribution of iron (and the other associated trace metals) may be strongly modified depending on the redox conditions in sediments and on the production of sulphides. In anoxic pore waters, iron was assumed to be present as $\mathrm{Fe}(\mathrm{II})$. When OM was not included in the model, thermodynamic equilibrium calculations indicated a saturation of troillite (FeS) precipitates at the three sites. In Spiere pore waters, which were characterized by the lowest dissolved iron concentrations, the addition of humic substances with the NICA-Donnan model resulted in a drop of free $\mathrm{Fe}^{2+}$ (less than 10\%) and a slight undersaturation towards FeS precipitates. The predicted complexation of iron with humic or fulvic acids seems to be overestimated in Spiere porewaters using the NICA-Donnan model. Conversely, the Stockholm Humic Model led to a very low contribution of iron organic forms (less than 1\%) and to a saturation of FeS in pore 
waters. Additional experiments should be carried out in the future to better understand the role played by organic matter on iron speciation in anoxic porewaters.

The formation of other metal sulphides MeS is influenced by kinetic constraints, which may significantly differ among trace metals. Morse and Luther (1999) demonstrated that Mn, Zn, $\mathrm{Cd}$ and $\mathrm{Pb}$ are expected to precipitate as their own sulphide compounds whereas $\mathrm{Co}$ and $\mathrm{Ni}$ tend to be adsorbed onto iron sulphides or incorporated in pyritic compounds. These two categories of divalent trace metals will be discussed separately in the following paragraphs. Whatever the site and the depth, MnS was undersaturated $(S \mid<0)$ so that Mn should be mostly inserted in iron sulphides. Its incorporation in the pyritic compounds remains rather hypothetic since this process starts from a DOP (degree of pyritisation) higher than 0.4 (Morse and Luther, 1999) and DOP values in our sediments never exceeded 0.2. The complexation of manganese with organic matter was low in porewaters (see section 3.3) and also probably in sediment particles as the fraction of manganese bound to the organic and sulphides fraction accounted for less than 5\% (extraction step 3, Figure 4). Finally, there is a good agreement between the high concentrations of manganese in porewaters, mostly present as $\mathrm{Mn}^{2+}$, and the solid partitioning, where about $80 \%$ of particulate $\mathrm{Mn}$ were included in the two most labile fractions ("exchangeable and carbonate" and oxide fractions). According to Morse and Luther (1999), cadmium, lead and zinc precipitate rather as MeS than with iron sulphides. With no OM inputs in the thermodynamic equilibrium modelling, $\mathrm{PbS}, \mathrm{CdS}$ and $\mathrm{ZnS}$ were greatly oversaturated (Table 1). The consideration of humic substances in our calculations made the results more realistic, especially for lead and zinc in Wervik and Helkijn sediments. In Spiere pore waters, saturation indexes were even more positive, but as the sulphide pool constituted of AVS and CRS in Spiere sediments was really high, the sulphidization of organic matter (e.g. thiol and polysulphide functional groups) can result in an underestimation of the binding capacity of organic matter (Luther-III and Church, 1992). For cadmium, a systematic oversaturation of CdS was noticed suggesting that the free $\mathrm{Cd}^{2+}$ in pore waters was always overestimated. The apparent oversaturation of $\mathrm{Cd}, \mathrm{Pb}$ and $\mathrm{Zn}$ towards sulphides may be due to the lack of data inside the database and/or the 
presence of metals in the colloidal fraction $(<0.45 \mu \mathrm{m})$, that is considered as truly dissolved in our calculations. For instance, Luther III and Rickard (2005) and Rozan et al. (2000) emphasised the presence of metal sulphide clusters, that are relatively stable, even in an oxygen rich water column.

In sediment particles, the high affinities of cadmium, zinc and lead for sulphides and organic matter are clearly shown in Figure 4 . More than $80 \%$ of $\mathrm{Cd}, \mathrm{Pb}$ and $\mathrm{Zn}$ was generally associated to the second and third fractions of the sequential extraction procedure. In Spiere, lead and cadmium were mostly associated to pyritic compounds and/or organic matter whereas, in Helkijn and Wervik sediments, they were rather included in the remaining oxides and/or not well cristallized sulphides.

Cobalt and nickel were significantly present in the third fraction of the sequential extraction procedure (10-30 \% and 15-35\% respectively), especially in Spiere sediments, where CRS contents were the highest. The incorporation of $\mathrm{Ni}$ and $\mathrm{Co}$ in pyritic compounds was the main way for these metals to be associated with sulphides. A fraction was also probably associated with organic matter, as suggested by the important fraction of nickel, and to a lesser extent $\mathrm{Co}$, that was associated with $\mathrm{OM}$ in pore waters. Nickel was also saturated towards one of its pure sulphide minerals NiS, called millerite. For cobalt, the results were less clear because the saturation index values were always found negative towards $\operatorname{CoS}_{\alpha}$ and clearly positive towards $\mathrm{CoS}_{\beta}$. However, the $8-29 \%$ of $\mathrm{Co}$ and $\mathrm{Ni}$ extracted in the second step were probably linked to these sulphide minerals and additionally associated to the remaining oxides, as suggested by the low DOS values found in the three cores.

Overall, from these results, organic matter and sulphides compete for the binding of trace metals in anoxic sediments. According to our calculations, dissolved sulphides tend to precipitate trace metals in the AVS and CRS pool, whereas organic matter seems to stabilize the metals in pore waters, especially $\mathrm{Zn}, \mathrm{Cd}$ and $\mathrm{Pb}$, through Me-OM associations. As organic matter is also able to stabilize a part of the colloidal fraction (Wilkinson et al., 1997), we may assume that $\mathrm{OM}$ is mainly responsible for trace metal mobility in anoxic sediments. Qualitatively, these results may contribute to predict the evolution of trace metals mobility in 
case of the sediment particles are subject to redox and/or $\mathrm{pH}$ changes. For instance, resuspension events in oxic overlying water can be responsible for a quick release of dissolved trace metals via the reoxidation of labile sulphides (Saulnier and Mucci, 2000). But the subsequent precipitation of $\mathrm{Fe}(\mathrm{III})$ hydroxides tends to counteract the mobility of metals through adsorption and/or (co)precipitation processes. Conversely, organic ligands may stabilize trace metals as dissolved species. However, the complexation of trace metals by OM can take several hours (Louis et al. 2009), so that OM could be considered to play a limited role when quick exchanges occur in the sediments. Another interesting study case would be the depletion of oxygen and iron hydroxides at the water-sediment interface due to eutrophication events. In this case, the release of trace metals would be accelerated by the presence of Me-OM complexes in the pore waters and the disappearance of the oxic barrier at the water-sediment interfacial layer.

\section{Conclusion}

The behaviour of trace elements in Spiere, Helkijn and Wervik sediments was studied from both experimental results and thermodynamic equilibrium calculations. The results presented by Lesven et al. (2008) were dedicated to the early diagenetic processes that occurred in core sediments from this area. Particular attention was paid to the sulphidization processes that at least partly control the mobility of trace metals in particles and pore waters. The lability of the trace metals was only studied in pore waters, by comparing the data obtained from total concentration measurements and from DGT and DET probes. This purely experimental approach permitted to rank the studied metals according to their lability.

In this second article, metal speciation and distribution in the dissolved and solid phases were assessed by combining results of an experimental (a sequential extraction procedure) and a theoretical approach (thermodynamic equilibrium calculations). For the theoretical approach, experimental results reported by Lesven et al. (2008) were used. New insight was gained about the mobility of the trace metals in anoxic environments especially on the 
competition between organic matter and sulphides to bind trace metals, whereas carbonates do not play a significant role in the mobility of trace metals, except for manganese.

It had been found that cobalt and nickel were the two most labile elements, followed by cadmium and finally lead. In this paper, thermodynamic equilibrium calculations were performed to predict the speciation for each element, and also to show how dissolved organic matter could compete with inorganic ligands for the complexation of trace metals.

Overall, $\mathrm{Mn}, \mathrm{Co}$ and $\mathrm{Ni}$ were mainly present as free cation or associated with inorganic ligands. Conversely, we have shown that humic substances were the main ligands associated to dissolved lead, zinc and cadmium. By assuming that the availability of a metal can be related to its inorganic fraction, a similar ranking than the one previously obtained by Lesven et al. (2008) has been established in pore waters: $\mathrm{Mn}>\mathrm{Co} \sim \mathrm{Ni}>\mathrm{Cd}>\mathrm{Zn}>\mathrm{Pb}$. Thermodynamic equilibrium calculations have also been used to predict the formation of several precipitates, which may be hardly detected in anoxic sediments using spectroscopic or microscopic techniques. These results were also compared to those obtained from sequential extraction experiments. Iron solubility in pore waters was mainly controlled by sulphides, but also at several depths by carbonates. Manganese may not form any pure minerals since it is mostly present in calcite minerals, and to a lesser extent in oxides and/or iron sulphides. According to our calculations, $\mathrm{Co}, \mathrm{Ni}, \mathrm{Pb}$ and $\mathrm{Zn}$ concentrations in pore waters were not controlled by their carbonates, but rather by their sulphides and humic substances. $\mathrm{Cd}^{2+}$ was clearly over-saturated towards $\mathrm{CdS}$ whatever the site, suggesting an underestimation of the complexing capacity of natural organic matter and/or sulphides and polysulphides.

Assuming that the first fraction of the sequential extraction experiments is the most labile in sediment particles, a new lability ranking for metals in the three sediment cores has been established: $\mathrm{Mn}>>\mathrm{Fe} \sim \mathrm{Ni} \sim \mathrm{Co}>\mathrm{Zn}>\mathrm{Cd}>\mathrm{Pb}$. The ranking of the trace metals in both liquid and solid phases indicate that their lability in one of the phases is a good fingerprint of their behaviour in the other phase. 
Our findings suggest that organic matter and sulphides play a key role in the fate of trace metals in anoxic sediments. The low concentrations of trace elements in pore waters were mostly due to sulphide minerals that efficiently scavenge the trace metals as pure minerals and/or co-precipitation. Conversely, organic matter was responsible for trace metal stabilization in pore waters, especially for $\mathrm{Zn}, \mathrm{Cd}$ and $\mathrm{Pb}$. Without organic matter, the dissolved concentrations of the latter elements would have been at least $10^{3}$ lower. While sediments are considered as an efficient trap for trace metals because of its sulphide pool, several events may result in opposite effects: for instance, an important input of organic matter at the surface of sediments could favour the release of organic metal complexes in the water column due to the disappearance of the oxidised layer at the water-sediment interface. Additional studies are going on in our group to better understand trace metal exchanges at the water-sediment interface through laboratory experiments and field measurements.

\section{Acknowledgments}

This work has been funded in the framework of the INTERREG III "Stardust" research project. The authors would like to thank Christine Grare and Romain Descamps for their technical assistance. The authors are also grateful to the Water Agency "Artois-Picardie" and the Region Nord-Pas-de-Calais for the doctoral grant of Adeline Charriau.

\section{References}

Audry, S., Grosbois, C., Bril, H., Schäfer, J., Kierczak, J., Blanc, G., 2010. Post-depositional redistribution of trace metals in reservoir sediments of a mining/smelting-impacted watershed (the Lot River, SW France), Appl. Geochem. 25, 778-794.

Baker, L.A, 1994. Environmental Chemistry of Lakes and Reservoirs, Adv. Chem. Ser. 237, pp 627.

Balistrieri, L.S., Blank, R.G., 2008. Dissolved and labile concentrations of $\mathrm{Cd}, \mathrm{Cu}, \mathrm{Pb}$, and $\mathrm{Zn}$ in the South Fork Coeur d'Alene River, Idaho: Comparisons among chemical 
equilibrium models and implications for biotic ligand models. Appl. Geochem. 23, $3355-3371$.

Batina, N., Ciglenecki, I., Cosovic, B., 1992. Determination of elemental sulphur, sulphide and their mixtures in electrolyte solutions by a.c. voltammetry. Anal. Chim. Acta 267, 157-164.

Benedetti, M.F., Milne, C.J., Kinniburgh, D.G., Van Riemsdijk, W.H., Koopal, L.K., 1995. Metal Ion Binding to Humic Substances: Application of the Non-Ideal Competitive Adsorption Model. Environ. Sci. Technol. 29, 446-457.

Berner, R.A., 1984. Sedimentary pyrite formation: An update. Geochim. Cosmochim. Ac. 48, 605-615.

Billon, G., 2001. Géochimie des métaux et du soufre dans les sédiments des estuaires de la Seine et de l'Authie. PhD Thesis. Université des Sciences et Technologies de Lille, France, p. 206.

Billon, G., Ouddane, B., Boughriet, A., 2001a. Artefacts in the speciation of sulfides in anoxic sediments. The Analyst 126, 1805-1809.

Billon, G., Ouddane, B., Boughriet, A., 2001b. Chemical speciation of sulfur compounds in surface sediments from three bays (Fresnaye, Seine and Authie) in northern France, and identification of some factors controlling their generation. Talanta 53, 971-981.

Billon, G., Ouddane, B., Laureyns, J., Boughriet, A., 2001c. Chemistry of metal sulfides in anoxic sediments. Phys. Chem. Chem. Phys. 3, 3586-3592.

Billon, G., Ouddane, B., Recourt, P., Boughriet, A., 2002. Depth Variability and some Geochemical Characteristics of Fe, Mn, Ca, Mg, Sr, S, P, Cd and Zn in Anoxic Sediments from Authie Bay (Northern France). Estuar. Coast. Shelf. S. 55, 167-181.

Billon, G., Ouddane, B., Laureyns, J., Boughriet, A., 2003. Analytical and thermodynamic approaches to the mineralogical and compositional studies on anoxic sediments. J. Soil. Sediment. 3, 180-187. 
Borja, A., Valencia, V., Franco, J., Muxika, I., Bald, J., Belzunce, M.J., Solaun, O., 2004. The water framework directive: water alone, or in association with sediment and biota, in determining quality standards? Mar. Pollut. Bull. 49, 8-11.

Caetano, M., Madureira, M.J., Vale, C., 2003. Metal Remobilisation during Resuspension of Anoxic Contaminated Sediment: Short-Term Laboratory Study. Water Air Soil. Poll. 143, 23-40.

Canavan, R.W., Van Cappellen, P., Zwolsman, J.J.G., van den Berg, G.A., Slomp, C.P., 2007. Geochemistry of trace metals in a fresh water sediment: Field results and diagenetic modeling. Sci. Total Environ. 381, 263-279.

Canfield, D.E., Raiswell, R., Westrich, J.T., Reaves, C.M., Berner, R.A., 1986. The use of chromium reduction in the analysis of reduced inorganic sulfur in sediments and shales. Chem. Geol. 54, 149-155.

Cantwell, M.G., Burgess, R.M., Kester, D.R., 2002. Release and Phase Partitioning of Metals from Anoxic Estuarine Sediments during Periods of Simulated Resuspension. Environ. Sci. Technol. 36, 5328-5334.

Charriau, A., 2009. Etude de la contamination organique et métallique associée aux sédiments du District Hydrographique International de l'Escaut. PhD Thesis. Université Lille 1, France, p. 241.

Charriau, A., Bodineau, L., Ouddane, B., Fischer, J.C., 2009. Polycyclic Aromatic Hydrocarbons and n-alkanes in sediments of the Upper Scheldt River Basin: contamination levels and source apportionment. J. Environ. Monitor. 11, 1086-1093.

Cornwell, J.C., Morse, J.W., 1987. The characterization of iron sulfide minerals in anoxic marine sediments. Mar. Chem. 22, 193-206.

Crane, M., 2003. Proposed development of Sediment Quality Guidelines under the European Water Framework Directive: a critique. Toxicol. Lett. 142, 195-206.

Crocket, J.H., Winchester, J.W., 1966. Coprecipitation of zinc with calcium carbonate. Geochim. Cosmochim. Acta 30, 1093-1109. 
Davis, J.A., Fuller, C.C.,Cook, A.D., 1987. A model for trace metal sorption processes at the calcite surface: Adsorption of $\mathrm{Cd}^{2+}$ and subsequent solid solution formation. Geochim. Cosmochim. Acta 51, 1477-1490.

DiToro, D.M., Mahony, J.D., Hansen, D.J., Scott, K.J., Hicks, M.B., Mayr, S.M., Redmond, M.S., 1990. Toxicity of cadmium in sediments : the role of Acid Volatile Sulfide. Environ. Toxicol. Chem. 9, 1487-1502.

Filella, M., Town, R.M., 2005. A Framework for Interpretation and Prediction of the Effects of Natural Organic Matter Heterogeneity on Trace Metal Speciation in Aquatic Systems. In: Heidelberg SB, editor. Environmental Chemistry Green Chemistry and Pollutants in Ecosystems, pp. 121-132.

Gustafsson, J.P., 2001. Modeling the Acid-Base Properties and Metal Complexation of Humic Substances with the Stockholm Humic Model. J. Colloid. Interf. Sci. 244, 102112.

Hjorth, T., 2004. Effects of freeze-drying on partitioning patterns of major elements and trace metals in lake sediments. Anal. Chim. Acta 526, 95-102.

Huerta-Diaz, M.A., Tessier, A., Carignan, R., 1998. Geochemistry of trace metals associated with reduced sulfur in freshwater sediments. Appl. Geochem. 13, 213-233.

Jorgensen, B.B., 1982. Mineralization of organic matter in the sea bed - the role of sulphate reduction. Nature 296, 643-645.

Kersten, M., Forstner, U., 1986. Chemical fractionation of heavy metals in anoxic estuarine and coastal sediments. Water Sci. Technol. 18, 121-130.

Kramer, J.R., Allen, H.E., 1988. Metal Speciation: Theory, Analysis and Application. Chelsea: Lewis Publishers.

Larner, B.L., Palmer, A.S., Seen, A.J., Townsend, A.T., 2008. A comparison of an optimised sequential extraction procedure and dilute acid leaching of elements in anoxic sediments, including the effects of oxidation on sediment metal partitioning. Anal. Chim. Acta 608, 147-157. 
Lesven, L., Gao, Y., Billon, G., Leermakers, M., Ouddane, B., Fischer, J.C., Baeyens, W., 2008. Early diagenetic processes aspects controlling the mobility of dissolved trace metals in three riverine sediment columns. Sci. Total Environ. 407, 447-459.

Louis, Y., Garnier, C., Lenoble, V., Mounier, S., Cukrov, N., Omanović, D., Pižeta, I., 2009. Kinetic and equilibrium studies of copper-dissolved organic matter complexation in water column of the stratified Krka River estuary (Croatia). Mar. Chem. 114, 110-119.

Lourino-Cabana, B., Lesven, L., Billon, G., Proix, N., Recourt, P., Ouddane, B., Fischer, J.C., Boughriet, A., 2010. Impacts of Metal Contamination in Calcareous Waters of Deûle River (France): Water Quality and Thermodynamic Studies on Metallic Mobility. Water Air Soil Poll. 206, 187-201.

Luther-III, G.W., Church, T.M., 1992. An Overview of the Environmental Chemistry of Sulphur in Wetland Systems. In: Howarth RW, Stewart JWB, Ivanov MV, editors. Sulphur Cycling on the Continents. 48. John Wiley \& Sons, Toronto, pp. 125-144.

Luther III, G.W., Rickard, D.T. 2005. Metal sulfide cluster complexes and their biogeochemical importance in the environment. J. Nanopart. Res. 7, 389-407.

Mayer, T., Rochfort, Q., Borgmann, U., Snodgrass, W., 2008. Geochemistry and toxicity of sediment porewater in a salt-impacted urban stormwater detention pond. Environ. Pollut. 156, 143-151.

Meylan, S., Odzak, N., Behra, R., Sigg, L., 2004. Speciation of copper and zinc in natural freshwater: comparison of voltammetric measurements, diffusive gradients in thin films (DGT) and chemical equilibrium models. Anal. Chim. Acta 510, 91-100.

Miller, J.R., Orbock Miller, S.M., 2007. Contaminated Rivers: An Overview. In: Miller J.R. and Orbock Miller S.M., editors. Contaminated Rivers. A Geomorphological-Geochemical Approach to Site Assessment and Remediation. Dordrecht: Springer Netherlands; pp. $1-31$.

Morse, J.W., Arakaki, T., 1993. Adsorption and coprecipitation of divalent metals with mackinawite (FeS). Geochim. Cosmochim. Acta 57, 3635-3640. 
Morse, J.W., Luther, G.W., 1999. Chemical influences on trace metal-sulfide interactions in anoxic sediments. Geochim. Cosmochim. Acta 63, 3373-3378.

Ouddane, B., Boust, D., Martin, E., Fischer, J.C., Wartel, M., 2001. The post-depositional reactivity of iron and manganese in the sediments of a macrotidal estuarine system. Estuar. Coast. 24, 1015-1028.

Peltier, E., Dahl, A.L., Gaillard, J.F., 2005. Metal Speciation in Anoxic Sediments: When Sulfides Can Be Construed as Oxides. Environ. Sci. Technol. 39, 311-316.

Pingitore Jr, N.E., Lytle, F.W., Davies, B.M., Eastman, M.P., Eller, P.G., Larson, E.M., 1992. Mode of incorporation of $\mathrm{Sr}^{2+}$ in calcite: Determination by $\mathrm{X}$-ray absorption spectroscopy. Geochim. Cosmochim. Ac. 56, 1531-1538.

Pingitore, N.E., Eastman, M.P., Sandidge, M., Oden, K., Freiha, B., 1988. The coprecipitation of manganese(II) with calcite: an experimental study. Mar. Chem. 25, 107-120.

Quevauvillier, P., Rauret, G., López-Sánchez, J.F., Rubio, R., Ure, A., Muntau, H., 1996. EUR 17554. The certification of the EDTA-extractable contents (mass fractions) of $\mathrm{Cd}, \mathrm{Cr}, \mathrm{Ni}, \mathrm{Pb}$ and $\mathrm{Zn}$ in sediment following a three-step sequential extraction procedure - CRM 601. European Commission. BCR information series, pp. 59.

Rapin, F., Tessier, A., Campbell, P.G.C., Carignan, R., 1986. Potential artifacts in the determination of metal partitioning in sediments by a sequential extraction procedure. Environ. Sci. Technol. 20, 836-840.

Rauret, G., López-Sánchez, J.F., Sahuquillo, A., Rubio, R., Davidson, C., Ure, A., Quevauvillier, P., 1999. Improvement of the BCR three step sequential extraction procedure prior to the certification of new sediment and soil reference materials. J. Environ. Monitor. 1, 57-61.

Rickard, D., Morse J.W., 2005. Acid volatile sulfide (AVS). Mar. Chem. 97, 141-197.

Rozan, T.F., Lassman, M.E., Ridge, D.P., Luther III, G.W. 2000. Evidence for iron, copper and zinc complexation as multinuclear sulphide clusters in oxic rivers. Nature 406, 879-882. 
Saulnier, I., Mucci, A., 2000. Trace metal remobilization following the resuspension of estuarine sediments: Saguenay Fjord, Canada. Appl. Geochem. 15, 191-210.

Stumm, W., Morgan, J.J., 1981. Aquatic Chemistry: An Introduction Emphasizing Chemical Equilibria in Natural Waters, New York: Wiley-Interscience Publication.

Tesoriero, A.J., Pankow, J.F., 1996. Solid solution partitioning of $\mathrm{Sr}^{2+}, \mathrm{Ba}^{2+}$, and $\mathrm{Cd}^{2+}$ to calcite. Geochim. Cosmochim. Ac. 60, 1053-1063.

Tessier, A., Turner, D.R., 1995. Metal Speciation and Bioavailability in Aquatic Systems. IUPAC Series on Analytical and Physical Chemistry of Environmental Systems. Chichester: John Wiley \& Sons.

Tipping, E., 2002. Cation binding by humic substances. Cambridge University Press. Ure, A.M., Davidson, C.M., 2002. Chemical Speciation in the Environment. 2nd ed. Oxford: Blackwell Science.

van den Berg, G.A., Gustav Loch, J.P., van der Heijdt, L.M., Zwolsman, J.J.G., 1999. Mobilisation of Heavy Metals in Contaminated Sediments in the River Meuse, The Netherlands. Water Air Soil Poll. 116, 567-586.

Visual MINTEQ, 2010. Visual MINTEQ. A free equilibrium speciation model. http://www.Iwr.kth.se/English/OurSoftware/vminteq/ (accessed June 2010).

Wallmann, K., Kersten, M., Gruber, J., Förstner, U., 1993. Artifacts in the Determination of Trace Metal Binding Forms in Anoxic Sediments by Sequential Extraction. Int. J. Environ. An. Ch. 51, 187-200.

Wilkinson, K.J., Negre, J.C. Buffle, J. 1997. Coagulation of colloidal material in surface waters: the role of natural organic matter. J. Contam. Hydrol. 26, 229-243.

\section{Figure captions}

Figure 1. Map of the Scheldt River basin and location of the sampling sites: Helkijn on the Scheldt Canal $(H)$, Spiere on the Spiere Canal $(S)$ and Wervik on the Lys Canal $(W)$. 
Figure 2. Percentages of free ions $\left(\mathrm{Me}^{2+}\right)$, metal-sulphide complexes, other metal-inorganic complexes and metal-organic complexes (with fulvic and humic acids) calculated with Visual Minteq for cadmium, cobalt and iron in pore waters. For each sediment core, results are presented at three depths $(-3,-7$ and $-15 \mathrm{~cm})$ and with two different modelling: without organic matter (no OM) and with organic matter (NICA-Donnan).

Figure 3. Percentages of free ions $\left(\mathrm{Me}^{2+}\right)$, metal-sulphide complexes, other metal-inorganic complexes and metal-organic complexes (with fulvic and humic acids) calculated with Visual Minteq for manganese, nickel, lead and zinc in pore waters. For each sediment core, results are presented at three depths $(-3,-7$ and $-15 \mathrm{~cm})$ and with two different modelling: without organic matter (no OM) and with organic matter (NICA-Donnan).

Figure 4. Distribution of particulate cadmium, cobalt, iron, manganese, nickel, lead and zinc in the four sequential extraction fractions: exchangeable and carbonates, reducible, oxidizable and residual, as previously defined by Rauret et al. (1999). 